\title{
Consumer to Consumer (C2C) Online Auction Transaction Intentions: an Application of the Theory of Planned Behaviour
}

\author{
Dr. Christopher McLaughlin \\ Department of Hospitality and Tourism Management, Ulster University Business School \\ Coleraine, Ireland. \\ Dr. Laura Bradley \\ Department of International Business, Ulster University \\ Derry, Ireland. \\ Dr. Garry Prentice \\ Department of Psychology, Dublin Business School \\ Dublin, Ireland. \\ Ms Emma-Jayne Verner \\ Postgraduate \\ Department of Psychology, Dublin Business School \\ Dublin, Ireland.

\begin{abstract}
Dr. Sharon Loane
Business and Management Research Institute, Ulster University Business School

Derry, Ireland.
\end{abstract} \\ (C) Christopher McLaughlin, Laura Bradley, Garry Prentice, Emma-Jayne Verner and Sharon \\ Loane. This work is licensed under the Creative Commons Attribution-NonCommercial- \\ ShareAlike 4.0 International License. To view a copy of this license, visit \\ https://creativecommons.org/licenses/by-nc-sa/4.0/ .
}

\section{Abstract}

There has been a dramatic growth of individuals using online auctions especially within Consumer-to-Consumer (C2C) e-commerce coupled with increasing academic attention to behaviour in the online environments. Literature has identified the influence of attitudes, perceptions, trust and security on individual's online auction transaction intentions and behaviours. The aim of this study, therefore, was to predict and understand individuals online auction transaction intentions and behaviours through the application of the Theory of Planned Behaviour (TPB). Three hundred and seventy-two respondents completed the survey within two geographical regions. Findings reported that attitudes, self-efficacy and trust significantly influenced intentions; while intentions and self-efficacy significantly influenced online auction behaviours. Interestingly, social pressures, perceived control and security failed to have any influence. Overall, the study provided greater insight into which salient drivers influence transaction behaviours and intentions. 
Keywords: Consumer behaviour; Theory of Planned Behaviour; Attitudes; Online auctions; Trust; Security

\section{Summary statement of contributions}

The discovery of attitudes, personal abilities, trust and intentions as influential factors within the current research further highlights the need for online auction site marketing messages that emphasise aspects, like convenience and ease of use, while enhancing consumer confidence in the service provider. The attitude and satisfaction related variables identified in the current research are invaluable in terms of attracting new online auction site consumers, and retaining the existing consumer base.

\section{Introduction}

The overall aim of this study is to examine the antecedents of online auction purchasing and selling transactions through an application of the Theory of Planned Behaviour model (TPB: Ajzen, 1991) with the addition of both trust (Delafrooz, Paim and Khatibi, 2011) and security (Abbass and Ibrahim, 2011) factors. The medium of e-commerce is becoming more important with the numbers of online buyers and sellers increasing over the past number of years (Rauniar et al., 2009; Xu, Lin and Shao, 2010; Leonard, 2012). Furthermore, the success of customer-to-customer (C2C) transactions has grown over the past number of years and particularly in the area of online auctions (Chu and Liao, 2007). Online auctions such as eBay account for millions of transactions each day (Roggio, 2012; Armitstead, 2013; Music Trades Corporation, 2016). With high volumes of online auction transactions the issue, therefore, is not of how successful online auctions are, but rather to understand the salient influences that drive consumers to buy and sell in these marketplaces.

\section{Conceptual model development}

Consumers behave in different ways and are influenced by various stimuli which in turn influence their purchasing motivations, intentions and behaviours (Davidson, 2011); and understanding the role that these play is important for firms (Jack and Powers, 2013). The consumer behaviour process consists of several interlinked stages where consumers undertake a number of activities in relation to a purchase, such as information gathering and evaluation of purchase options and overall purchase (Engel, Kollatt and Blackwell, 1993; Gabbott and Hogg, 1998; Davidson, 2011). Numerous conceptual models have been developed to better understand this consumer behaviour process. Ajzen (2015) identifies both the Multi-Attribute Decision-Making (MADM) and the Subjective Expected Utility (SEU) approaches that have been applied to understand the decision-making of consumers. Within these approaches the consumer rates competing brands by their attributes, and inferences are made then about their choices. However, these approaches do not consider the role of social influences that can inform consumer's choices; for example, brand attributes presented may not be realistic or relevant to consumer choice due to various social influences (Ajzen, 2015). These models are more applicable to understanding choices around products or brands available online rather than consumer motivations, intentions and purchasing. 
There is one theoretical model which measures not only consumers' purchasing behaviours but also their intentions and motivations: this model is the TPB (Ajzen, 1991, 2002, 2011). Applying a theoretical framework model such as Ajzen's (1991) TPB would provide an integrated understanding of consumer's decisions and purchasing within an online auction. The TPB posits that consumer behaviours and decisions are influenced by motivations such as attitudes towards the behaviour, subjective-norm (SN) and perceived behaviour control (PBC: Ajzen, 1991, 2011). Within the theory, consumer behaviour can be influenced by the level of readiness, intention the individual holds in carrying out the behaviour, and the level of perceived behavioural control over carrying out the behaviour. Predicting purchasing intentions can be dependent on the strength of the consumer's attitudes, possible social pressures as measured through SN, and their PBC. Each of these motivational factors, and their role within the model, are addressed in the following sections.

\section{Motivations to use online auctions}

The increasing popularity of online auction marketplaces is due to several motivating factors that positively influence consumer attitudes, beliefs and experiences. Studies have identified key factors that influence attitudes towards online auctions; for instance, convenience (Burke, 1998; Li, Chung and Fiore 2017) and ease to locate products (Weinberg and Davis, 2005). Evidence suggests that those who believe online auctions are a more convenient way to shop, as they can easily find what they want to purchase or bid on, were likely to use the service more. In addition, consumers emphasise the importance of having a good experience while bidding during an auction (Saputra, Warokka and Naruephai, 2012). Thus, online auctions provide consumers with a convenient, easy and enjoyable way to purchase online. However further emphasis should be placed on the attitude-intention relationship (Ajzen, 2015; Schlaegel, 2015) and how attitudes influence transaction intentions (Schlaegel, 2015). Therefore, the current study tests the following hypothesis:

\section{H1 Favourable attitudes will positively influence intentions to use online auctions}

Previous literature has highlighted the importance of social motivations for online customers (Hou and Elliott, 2016; Li, Chung and Fiore, 2017): online consumers' enjoyment of their shopping experience due to their social interactions with other shoppers, family and friends (Hou and Elliott, 2016). So, the online purchasing process is not an isolating experience for many but rather one with much interpersonal communication, which in turn influences the consumer's perception of the website (Li, Chung and Fiore, 2017). Considering the present research, the role of social influences is viewed as a motivational factor to engage (Ajzen, 1991); social influences are measured by SN. According to Ajzen (1991), SN is the amount of influence the individual feels either to engage or not with the intended behaviour; thus, positive social influences would be more associated with increased likelihood to engage with online purchasing (Parsons, 2002; Rohm and Swaminathan, 2004). Recently, Lim et al. (2016) and Hasbullah et al. (2016) report that SN had a significant role in predicting online purchasing intentions. In both instances, consumers who had taken on the favourable views of others were more likely to purchase compared to those who did not. However, not all research is consistent 
with this; others have reported that the role of SN does not account for any influence on online auction purchase intentions (Huang et al., 2011). Thus, with such inconsistencies within the literature the current study explores the possible role of SN in predicting online auction intentions. Therefore, the current study tests the following hypothesis:

\section{H2 Favourable SN views will positively influence intentions to use online auctions}

Evidence reports that PBC has an important role in predicting consumers' intended use of online auctions (Bosnjak, Obermeier and Tuten, 2006; Huang et al., 2011), suggesting that those consumers receiving more encouragement have greater intentions to use online auction sites. Though PBC influences behaviour as well as intentions, not all research has shown this to be consistent (Bosnjak, Obermeier and Tuten, 2006). Bosnjak, Obermeier and Tuten (2006) report that PBC influences consumer intentions but not the number of bids they placed online; suggesting a further investigation of the PBC-behaviour relationship. Interestingly, Chen et al., (2007) when suggesting future research in relation to online auctions, stated that consumer's capabilities and self-efficacy should be taken into consideration. Similarly, Ajzen (1991) suggests that PBC can comprise of two distinct dimensions. Evidence suggests that internal (self-efficacy) and external (perceived) control may be related but not necessarily synonymous constructs (Terry and O'Leary, 1995; Conner and Armitage, 1998), but rather distinct (Lunardo, 2011). Self-efficacy focuses on individual internal abilities that may influence decisions to carry out the behaviour while perceived control takes into account the number of perceived barriers to overcome to carry out the behaviour (Terry and O'Leary, 1995; Armitage and Conner, 1999; Lunardo, 2011). Rather than just use both these terms interchangeably, it's important to provide clarification on the role of self-efficacy and perceived control in predicting consumer intentions and usage of online auctions. Based on this, four hypotheses are formulated:

H3 Increased levels of self-efficacy will positively influence intentions to use online auctions

H4 Increased levels of self-efficacy will positively influence frequency of online auction transactions

H5 Increased levels of perceived control will positively influence intentions to use online auctions

H6 Increased levels of perceived control will positively influence frequency of online auction transactions

Not only is it important to understand the role of control factors in predicting online auction use intentions and behaviours, but there is also a need to further understand user intentions to purchase (Abbass and Ibrahim, 2011). Not all previous research explores the link between intentions to use online and actual usage; some have only examined the antecedents of intentions (Huang et al., 2011). However, one recent meta-analytic study of online auctions reports the important role of intentions in 
predicting online auction usage but it recommended that more research needs to be conducted exploring the role of motivational factors and intentions on behaviours (Schlaegel, 2015). The TPB (Ajzen, 1991) theory provides a valuable approach to understanding these links. The theory proposes that increased intentions link to greater likelihood the individual will carry out the behaviour (Ajzen, 2015). Thus those consumers who express stronger intentions will be more likely to engage in online auction transactions. To explore the influence of intentions on behaviour, the following hypothesis is formulated:

\section{H7 Favourable intentions will influence more frequent online auction transactions}

Past research has successfully demonstrated the utility of the TPB model in explaining various online intentions and behaviours such as online trading intentions (Gopi and Ramayah, 2007), banking adoption (Lee, 2009), internet banking (Sanayei and Bahmani, 2012), self-protection intentions around online privacy (Yao and Linz, 2008), online shopping behaviours (Hsu et al., 2006; Pavlou and Fygenson, 2006; Hansen, 2008; Huang et al., 2011; Schlaegel, 2015) and behaviour (King, Dennis and Wright, 2008; Schlaegel, 2015). However, applying an expanded TPB (Ajzen, 1991) approach to understand online auction behaviours such as to sell or buy a product has been quite limited. Despite the limited application of Theory of Planned Behaviour to explain the influences on online auction behaviour, its merit and value as a tool to examine and explain behaviour is evident and longstanding (Schlaegel, 2015). Similarly, alternative online auction research has investigated intentions to use online auctions (Chen et al., 2007; Yen and Lu, 2008a, 2008b; Chiu et al., 2009; Huang et al., 2011) but also importantly the role of trust (Schlaegel, 2015) and security (Chen et al., 2007). The current study examines an expanded TPB model with the additional constructs of trust and security.

\section{Trust and security in online transactions}

Over the past few years there has been a growth in online auctions which are also central points for customer-to-customer (C2C) e-commerce (Leonard, 2012; Lu and Lin, 2012). Unlike B2C, where transactions are generally conducted online directly between the retailers and the customer, $\mathrm{C} 2 \mathrm{C}$ online auctions are done between the buyer and seller with the auction site overseeing the transaction. B2C online transactions are dyadic (seller and buyer) while C2C are triadic (seller, buyer and auction site) and trust would be placed differently within the transaction relationship. In B2C transactions the buyer is directly dealing with the retailer, a two-party transaction, where the buyer is the weaker party. In addition, the buyer would be aware of the reputation of the seller. However, in $\mathrm{C} 2 \mathrm{C}$ e-commerce auction transactions the buyer and seller are relatively unknown to each other even when taking into account other user reviews of past behaviour; this is referred to as information asymmetry (Chiu, Huang and Yen, 2010). Consumers' perceptions of risk associated with online marketplaces and variable knowledge of sellers impacts their social interactions with online auctions. Thus this online transaction is based on trust, for example for customers there is the expectation that the product they bought arrives in an appropriate condition (Schlaegel, 2015). However, untrustworthy sellers could exploit information asymmetry to serve themselves by misrepresenting the condition of the product. 
Trust enhances purchase intentions and customer retention (Gefen and Straub, 2004), and its influence is not underestimated (Chen and Barnes, 2007; Chiu, Huang and Yen, 2010). Therefore, trust can ultimately affect the relationship between econsumers and online providers (Gefen, Karahanna and Straub, 2003; Koufaris and Hampton-Sosa, 2004). However, most research within the area of trust and online transactions has focused on B2C and not C2C (Shareef et al., 2013). Furthermore, $\mathrm{Wu}$, Cheng and Yen (2014) argue that there has been limited detailed investigation of trust in $\mathrm{C} 2 \mathrm{C}$ online auctions.

Security factors surrounding the storage of personal information of users have been shown to have a significant role in the adoption or non-adoption of e-commerce (Yousafzai, Pallister and Foxall, 2003; Gregg and Walczak, 2008; Abdelghaffar and Moustafa, 2013). The role of trust and security within e-commerce transactions are related (Chellappa and Pavlou, 2002; Shareef et al., 2013) not only to each other, but also with the attitudes of users towards the service (George, 2002), which impact on consumer transactions (Vijayasarathy, 2004). The current study explores the role of trust and security further with the following hypotheses:

H8 Perceptions of trust will positively influence intentions to use online auctions

H9 Perceptions of trust will positively influence frequency of online auction transactions

H10 More favourable perceptions of security will positively influence intentions to use online auctions

H11 More favourable perceptions of security will positively influence frequency of online auction transactions

TPB research has provided important insights into understanding psychological motivations that underlie consumers' online auction intentions and behaviours (Pavlou and Fygenson, 2006; Huang et al., 2011) while expanded TPB models have provided further insights relating to additional antecedents of intentions and behaviours (Schlaegel, 2015). Within the current research trust and security are included alongside attitudes, SN and control factors in an expanded TPB model, to further understand their influences on online intentions and behaviours. The expanded TPB model tested in the current study is represented in Figure 1.

Figure 1: Expanded TPB model examining online auction transactions with associated hypotheses 


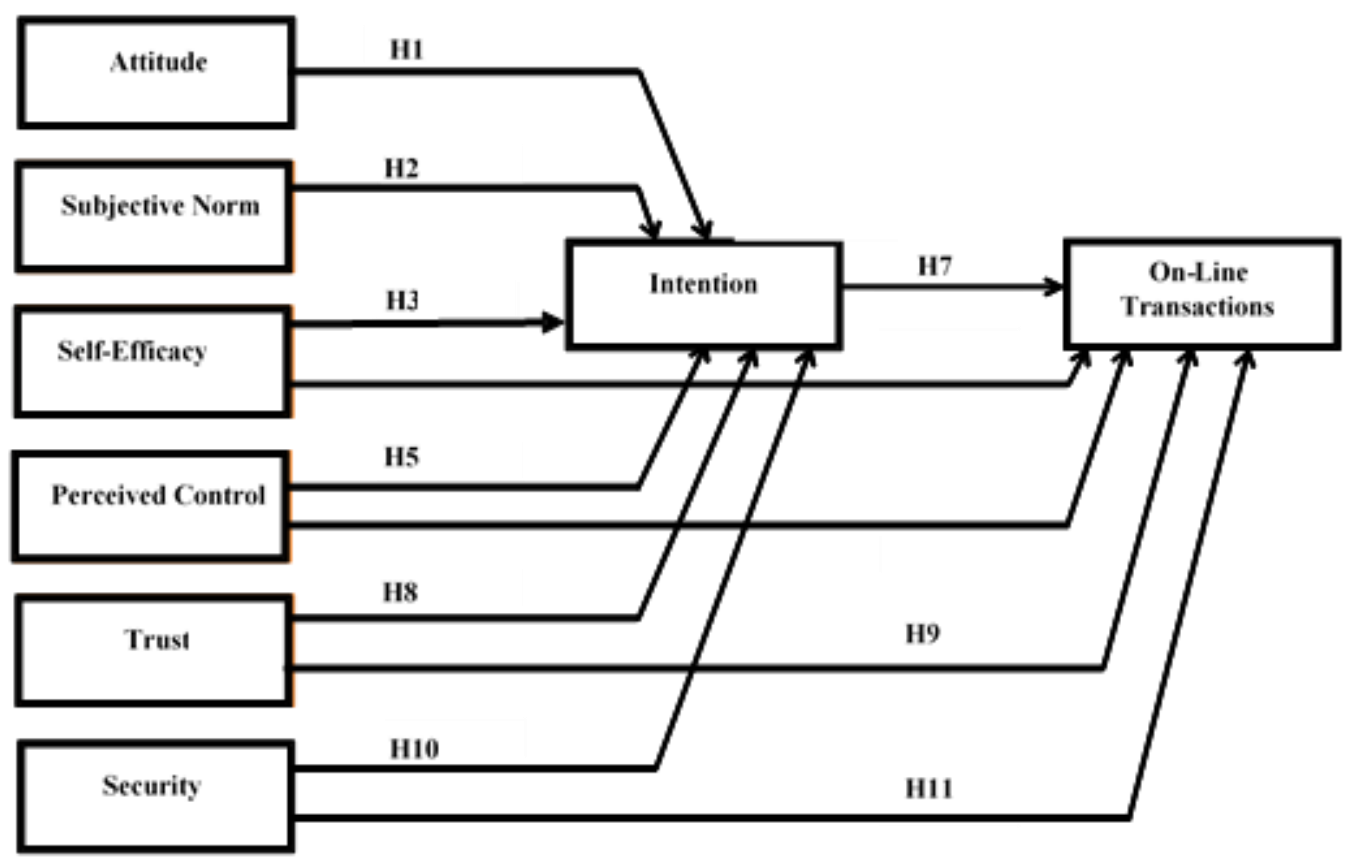

\section{Method}

\section{Sample and procedure}

Administration of the survey took place in two geographical locations within Northern Ireland and the Republic of Ireland to examine the robustness of the data over different national environments (Kautonen, van Gelderen, and Tornikoski, 2013). Due to the global presence of eBay the inclusion of more than one geographical region was an important aspect of this study. Participants in the study are representative of eBay UK (www.ebay.co.uk) and eBay Ireland (www.ebay.ie). Participants were recruited from a series of business events. All surveys were conducted in a face to face setting and contained an instruction sheet which explained how to complete the survey and semantic differential scales; additionally, all participants were informed they had the right to withdraw at any time. Statistical analysis employed IBM SPSS v22 for descriptive statistics, factor analysis and correlations and IBM AMOS v22 was used to test the hypothesised model. In total, there were three hundred and seventy-two $(N=372)$ participants who voluntarily took part in the survey; of which one hundred and fifty-four $(n=154)$ were males and one hundred and ninety-two $(n=192)$ were females. The average age was 24.59 years $(S D=7.43)$ for participants; with slightly more coming from a suburban $(\mathrm{n}=$ $136 ; 38.4 \%)$ background than urban $(n=109 ; 30.8 \%)$ or rural $(n=109 ; 30.8 \%)$ for those that responded. Most participants within the sample rated that they were buyers and sellers $(n=149 ; 41.6 \%)$ or sellers $(n=143 ; 39.9 \%)$ on the eBay auction site; however, fewer participants rated themselves either as just buyers $(n=4 ; 1.1 \%)$ or not using the service to buy or sell $(n=62 ; 17.3 \%)$. 


\section{Measures}

The questionnaire was developed to measure those constructs contained within the original TPB (Ajzen, 2002) and the application of TPB (Armitage and Conner, 2001) models; following recommendations for questionnaire design as suggested by Ajzen (2015). As outlined by Ajzen (2002), direct predictors were assessed on seven-point semantic differential scales. An instructional sheet explaining the seven-point scale used was provided to the respondents. All statements were based on action, context, target and time elements. Higher scores represented more online service use, more favourable attitudes, positive social influence and more perceived behavioural control over using an online auction site.

\section{Intention}

This construct measured an individual's motivation to use a globally renowned and established online auction service, namely eBay. There were three statements posed at various points within the questionnaire, requiring respondents to think about the likelihood of using an online auction within the next month. For example: 'How likely are you to use eBay to buy/sell an item in the next month?'

\section{Attitude toward the behaviour}

The direct measure of attitudes examined a respondent's affective feelings towards using an online auction service such as eBay using a set of six differential scale items; these included practical/impractical, complicated/uncomplicated, appealing/unappealing, good idea/bad idea, valuable/worthless and easy/difficult.

\section{Subjective norm}

At a direct level the measurement of subjective norm is the extent of how much importance the respondent views the role of 'significant others' in their life in endorsing them to use an online auction site to buy or sell an item. Each respondent was asked to evaluate the following statement: 'Most people who I know think that using eBay to sell or purchase an item in the next month is a good idea?'.

\section{Perceived behavioural control}

In regard to perceived behavioural control (PBC), nine items were employed to measure a respondent's confidence in using an online auction site to buy or sell an item within the next month. These included: "I would feel very confident to buy or sell an item on eBay within the next month' and 'I feel that I have no control over the selling or buying of an item on eBay if I were to use it.

\section{Trust and security}

In the expansion of the TPB model, two additional variables were included. Firstly, trust in online auctions was measured by one item: 'I don't trust a service like eBay when purchasing or selling an item'. The perception of security was also measured with one item: 'Providing personal information would discourage me from using eBay to buy or sell an item'. 


\section{Behaviour}

A respondent's frequency of eBay online auction behaviour was measured using one item. This item examined if the respondent had ever bought or sold something using an online auction site and was rated on an eight-point scale (not at all-daily).

\section{Results}

\section{Exploratory factor analysis}

Exploratory factor analysis (EFA) using maximum likelihood analysis with Direct Oblimin was used and factors with Eigenvalues over 1 were reported. Two factors emerged which accounted for $59.97 \%$ of variance (see Table 1 ). The results indicate that control perceptions in using an online auction site fall into two factors. Factor 1 would reflect confidence in an individual's ability to use an online auction site and can be referred to as self-efficacy, while Factor 2 reflected more perceived barriers or efforts regarding using an online auction site. This factor can be referred to as perceived control. Thus, this analysis suggests that the PBC element of this TPB model consists of two factors, self-efficacy and perceived control. The subsequent analyses include both these factors as separated rotated variables rather than one variable for PBC.

\section{Table 1: Exploratory Factor Analysis of PBC Items}

PBC items

'I would find using eBay as pretty straight forward'

'I know I would have the ability to use eBay'

'I would feel very confident using eBay'

'I feel that I would encounter very few problems using eBay'

'It would be difficult for me to be able to receive items bought on eBay'

'It would be difficult for me to be able to send items which I sold on eBay'

'I feel that I don't have enough capability either to sell or purchase an item on eBay'

I feel that I have no control over the selling or purchasing of an item on eBay'

'I feel using eBay in the next month would take too much time'

Eigenvalues

Percentage of variance 


\section{Descriptive and correlational analysis}

Descriptive statistics for each of the TPB and behaviour measures employed in the current study are displayed in Table 2. Alpha coefficients were favourable (Kline, 2005). Overall in relation to use of online auction sites intentions $(M=14.30, S D=$ 5.61), attitudes $(M=21.83, S D=8.39)$, self-efficacy $(M=13.18, S D=6.38)$, perceived control $(M=16.92, S D=6.48)$, security $(M=4.39, S D=1.85)$ and trust $(M$ $=3.59, S D=2.02$ ) were moderately favourable, while overall respondent behaviour $(M=6.79, S D=1.40)$ reflected very frequent online auction site use. However, the average rating of $S N(M=2.90, S D=1.50)$ was less favourable.

Zero-order correlations are also presented in Table 2 and it is evident that the strongest significant relationships with intentions to use the online auction site were with attitudes $(r=.73, p<.001)$, self-efficacy $(r=.57, p<.001)$ and trust $(r=.45, p<$ $.001)$. Furthermore, more moderate to weaker significant relationships with intentions were reported with the variables perceived control $(r=.31, p<.001)$, SN and security $(r=.14, p=.011)$. Lastly, behaviour was significantly related from strongly to moderately with intention $(r=.70, p<.001)$, attitude $(r=.55, p<.001)$, self-efficacy $(r=.50, p<.001)$, trust $(r=.42, p<.001)$ and perceived control $(r=.33, p<.001)$ while SN $(r=.18, p=.001)$ and security $(r=.14, p=.009)$ were significantly, yet weakly, related. Lastly, each of the predictor variables were related to the each of the criterion variables of intention and behaviour, supporting further examination of relationships through path analysis.

\section{Table 2: Descriptive and Inferential Statistics for Aggregate TPB Variables}

\begin{tabular}{|c|c|c|c|c|c|c|c|c|c|c|c|c|}
\hline & $\mathbf{M}$ & SD & Range & $\alpha$ & 1 & 2 & 3 & 4 & 5 & 6 & 7 & 8 \\
\hline 1. Intention & 14.30 & 5.61 & $3-21$ & .87 & --- & & & & & & & \\
\hline 2. Attitude & 21.83 & 8.39 & $6-42$ & .87 & $.73^{* * *}$ & --- & & & & & & \\
\hline 3. $\mathrm{SN}$ & 2.90 & 1.50 & $1-7$ & $\dagger$ & $.31^{* * *}$ & $.39^{* * *}$ & --- & & & & & \\
\hline 4. Self-efficacy & 13.18 & 6.38 & $4-28$ & .85 & $.57^{* * *}$ & $.67^{* * *}$ & $.38^{* * *}$ & --- & & & & \\
\hline 5. Perceived Control & 16.92 & 6.48 & $5-35$ & .76 & $.31^{* * *}$ & $.36^{* * *}$ & .01 & $.39^{* * *}$ & --- & & & \\
\hline 6. Security & 4.39 & 1.85 & $1-7$ & $\dagger$ & $.14^{*}$ & .09 & -.07 & .05 & $.24^{* * *}$ & --- & & \\
\hline 7. Trust & 3.59 & 2.02 & $1-7$ & $\dagger$ & $.45^{* * *}$ & $.44^{* * *}$ & $.16^{* *}$ & $.44^{* * *}$ & $.51^{* * *}$ & $.39^{* * *}$ & --- & \\
\hline 8. Behaviour & 6.79 & 1.40 & $1-8$ & $\dagger$ & $.70^{* * *}$ & $.55^{* * * *}$ & $.18^{* *}$ & $.50^{* * * *}$ & $.33^{* * * *}$ & $.14^{* *}$ & $.42^{* * * *}$ & --- \\
\hline
\end{tabular}

\section{Estimation of the TPB model}

The path analysis testing the TPB model is shown in Figure 1 and the overall fit of the model was reported (see Table 3 ) to be a good explanation of the relationships within the data $\left(X^{2}(372)=3.142, d f=2, p=.208\right.$, RMSEA =.039). The chi-square values in conjunction with the degrees of freedom were reported to be low and nonsignificant and the RMSEA was less than .05 (Browne and Cudeck, 1993; Hu and 
Bentler, 1999), thus indicating a close fit of the model to the data. Incremental fit indices were also employed for the evaluation of the model fit as suggested by Hoyle and Panter (1995,) and Miles and Shevlin (2007). The values indicated that the NFI (.997), IFI (.999), and TLI (.981) were all greater than the .95 cut off point and furthermore suggested that the tested model provided a good approximation and explanation of the data. Overall, based on the descriptive and incremental fit indices, the TPB model provided a good fit to the data.

Table 3: Path Coefficients and Fit Statistics of the TPB Model

\begin{tabular}{|c|c|c|c|c|c|c|}
\hline & (Hyp & potheses) & $R^{2}$ & $\begin{array}{c}\text { Path } \\
\text { coefficients }\end{array}$ & $p$ & $\begin{array}{l}\text { Hypothesis } \\
\text { supported }\end{array}$ \\
\hline (H1) Attitude & $\rightarrow$ & Intention & & .60 & .000 & Yes \\
\hline$(\mathrm{H} 2) \mathrm{SN}$ & $\rightarrow$ & Intention & & .01 & .877 & No \\
\hline (H3) Self-efficacy & $\rightarrow$ & Intention & .561 & .12 & .020 & Yes \\
\hline $\begin{array}{l}\text { (H5) Perceived } \\
\text { control }\end{array}$ & $\rightarrow$ & Intention & & .03 & .535 & No \\
\hline (H10) Security & $\rightarrow$ & Intention & & .03 & .414 & No \\
\hline (H8) Trust & $\rightarrow$ & Intention & & .14 & .004 & Yes \\
\hline (H7) Intention & & $\begin{array}{l}\text { On-line } \\
\text { Transactions }\end{array}$ & & .59 & .000 & Yes \\
\hline (H4) Self-efficacy & $\rightarrow$ & $\begin{array}{l}\text { On-line } \\
\text { Transactions }\end{array}$ & & .10 & .030 & Yes \\
\hline $\begin{array}{l}\text { (H6) Perceived } \\
\text { control }\end{array}$ & & $\begin{array}{l}\text { On-line } \\
\text { Transactions }\end{array}$ & .519 & .07 & .122 & No \\
\hline (H11) Security & & $\begin{array}{l}\text { On-line } \\
\text { Transactions }\end{array}$ & & .01 & .891 & No \\
\hline (H9) Trust & & $\begin{array}{l}\text { On-line } \\
\text { Transactions }\end{array}$ & & .07 & .131 & No \\
\hline \multicolumn{7}{|l|}{$\begin{array}{l}\text { Goodness of fit } \\
\text { statistics }\end{array}$} \\
\hline$X^{2}$ & & 3.14 & & & & \\
\hline Df & & 2 & & & & \\
\hline$P$ & & .208 & & & & \\
\hline RMSEA & & .039 & & & & \\
\hline \multicolumn{7}{|c|}{ Incremental fit indices } \\
\hline NFI & & .997 & & & & \\
\hline IFI & & .999 & & & & \\
\hline TLI & & .981 & & & & \\
\hline
\end{tabular}

Figure 2 and Table 3 illustrate the predictor variable relationships with intentions and behaviours regarding the use of an online auction site. Attitudes $(\gamma=.60 ; p<.001)$, 
self-efficacy $(\gamma=.12, p=.020)$ and trust $(\gamma=.14, p=.004)$ had significant relationships with intentions, with attitudes being the strongest predictor of intentions to use the online auction site. However, perceived control $(\gamma=.03, p=.535)$, SN $(\gamma=$ $.01, p=.877)$ and security $(\gamma=.03, p=.414)$ did not have any significant relationships with intentions. These factors accounted for $56 \%\left(R^{2}=.56\right)$ of variance in intentions to use an online auction site. In regard to predicting online behaviour, intentions $(B=.59, p<.001)$ had the strongest significant relationship with the criterion variable followed, to a lesser extent, by self-efficacy $(\gamma=.10, p=.030)$. The path analysis indicated that perceived control $(\gamma=.07, p=.122)$, trust $(\gamma=.07, p=$ $.131)$ and security $(\gamma=.01 ; p=.891)$ did not have significant relationships with online auction site behaviour. These factors accounted for $52 \%\left(R^{2}=.52\right)$ of variance in online auction site use behaviour.

Figure 2: Path Diagram of the applied TPB Model

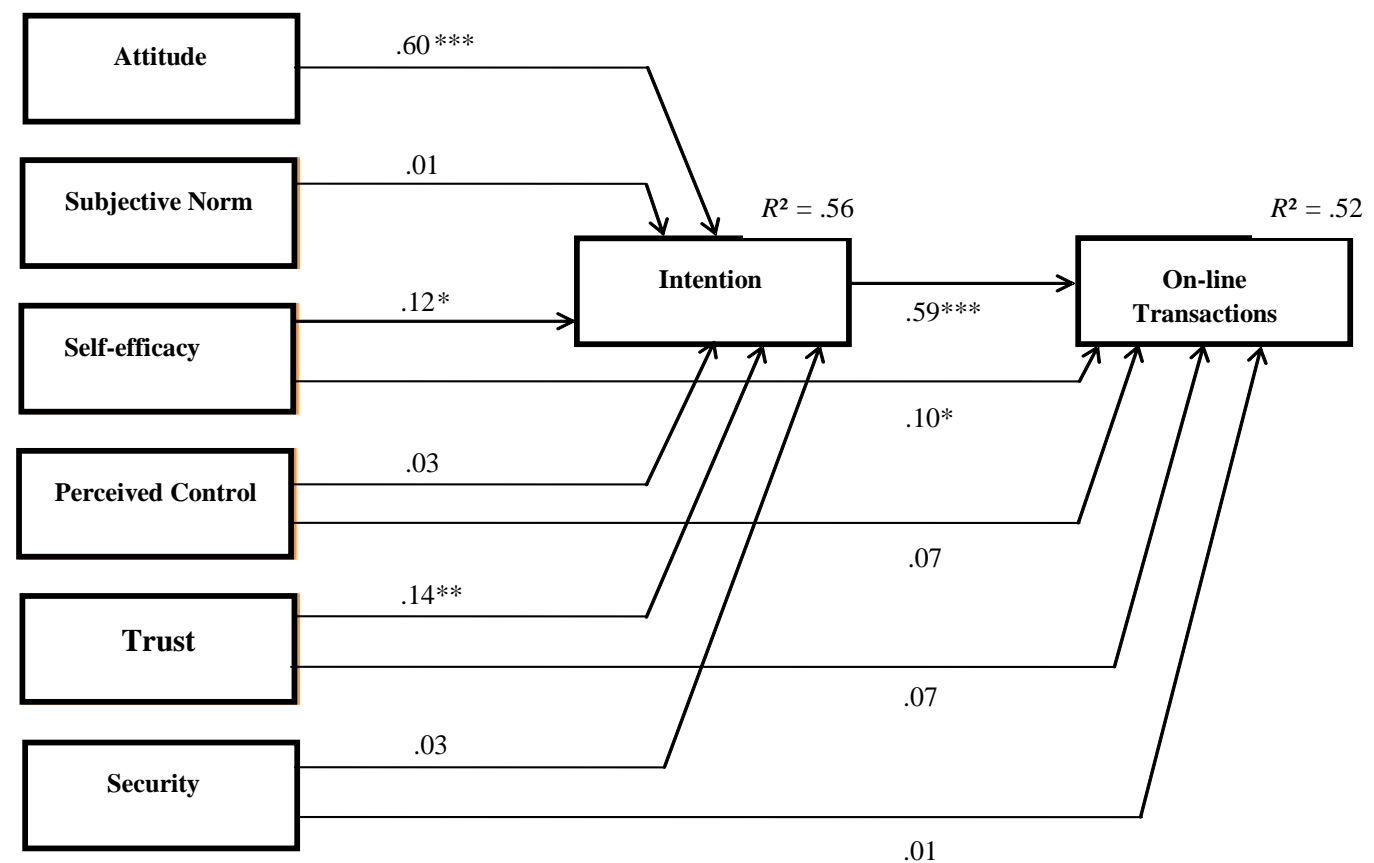

Note: * significant at the .05 level; ** significant at the .01 level; ${ }^{* * *}$ significant at the .001 .

\section{Discussion}

The overall aim of this study is to further understand the role motivational factors, trust, and security have in influencing consumer's online auction intentions and transaction behaviours. Overall the TPB (Ajzen, 1991) model provided a good 
explanation of online auction intentions and transaction behaviours and the evidence further supports previous suggestions that applying an expanded model such as the TPB can be beneficial (Schlaegel, 2015). Further evidence from the current findings show how attitudes (H1), social influences (H2), abilities (H3, H4, H5 and H6), trust ( $\mathbf{H 8}$ and $\mathrm{H} 9$ ) and perceptions of security (H10 and H11) influence consumer's online auction intentions and frequency of transactions, while also establishing the link between online auction intentions and frequency of transactions $(\mathbf{H 7})$.

\section{Predicting online auction intentions}

Within the current study TPB framework, attitudes towards using online auctions (H1) had the strongest influence on online auction intentions; suggesting that the more favourable the consumer's attitudes toward online auctions the more favourable their intentions to use such a service. This is consistent with other studies that found favourable attitudes to using an online auction are generally related to more bidding or selling transactions (Pavlou and Fygenson, 2006; Huang et al., 2011; Schlaegel, 2015). Thus, perceptions of transaction convenience, ease and success inform attitudes towards online auctions (Burke, 1998; Li, Chung and Fiore 2017) but also demonstrate the strength of the attitude-intention relationship regarding consumer's engagement with online auctions (Ajzen, 2015; Schlaegel, 2015).

Furthermore, the current study findings also reflect the inconsistent nature of SN (H2) as social or normative pressures neither increased nor decreased consumer's intentions to use an online auction site (Huang et al., 2011). This would mean that they did not view the expectations of others as important when considering using an online auction service like eBay, which contradicts the conclusions drawn by Rohm and Swaminathan (2004), and Parsons (2002). Thus the current study suggests that the opinions of friends, family and others do not necessarily influence the online auction decisions of consumers, even if these experiences are informative or cautionary. Therefore, it seems to be down to the consumer's own attitudes towards online auctions, rather than the opinions of others, that influence their transaction decisions.

The current study identified self-efficacy and perceived control as two constructs linking to PBC, which is consistent with previous research (Terry and O'Leary, 1995; Conner and Armitage, 1998; Lunardo, 2011). Apart from consumer attitudes, the only other construct within the TPB (Ajzen, 1991) that influenced online auction intentions was self-efficacy, suggesting that consumers with more confidence in their ability to use online auction sites were slightly more likely to intend to use online auction sites (H3). By separating PBC into two constructs it also becomes clearer that consumer confidence in their abilities is more important in predicting consumer intentions than perceptions around perceived control barriers. Consumers perceptions around barriers to engaging with online auctions did not have a significant influence on their intentions (H5), thus possible barriers to using online auctions do not seem to influence intentions to use the service. However, consumer confidence in their ability to engage with bidding, selling or purchasing within an auction marketplace was not as important as their attitudes toward the service. This current finding partially supports previous research, which explored the important 
role PBC has in prediction of online auction intentions (Pavlou and Fygenson, 2006; Huang et al., 2011; Schlaegel, 2015).

Although both trust (H8) and security $(\mathbf{H} 10)$ were included within the expanded TPB (Ajzen, 1991) model, only consumer's perceptions of trust had a significant but weak influence on intentions to use online auction sites. The current research supports previous findings with regard the role of trust in predicting online auction intentions (Chiu et al., 2010) but it also highlights that this role is secondary to the role of consumer attitudes. This is consistent with past research where consumer trust aligns with consumer online auction satisfaction levels regarding the bidding, purchasing and selling process (Schlaegel, 2015). Trust may have a role informing consumer intentions but a more important role could be informing consumer satisfaction levels. This further suggests that within $\mathrm{C} 2 \mathrm{C}$ online auctions trust may be an important issue around service quality and satisfaction for the consumer (Vijayasarathy, 2004). Despite the weak role for trust within the model, its statistically significant relationship with online auction intentions does provide more evidence of its, at least minor, role within the C2C transactions (Shareef et al., 2013). In contrast to previous findings, the impact of security in relation to storage of personal information by online auction services was non-significant in the current study (Abdelghaffar and Moustafa, 2013; Sanayei and Bahmani, 2012).

\section{Predicting online transaction behaviours}

As for predicting frequency of online auction behaviour, both consumer intentions (H7) and self-efficacy (H4) played a significant role. Consumer intentions had the stronger influence suggesting that when engaging with online auction bidding, purchasing or selling consumer's intentions, rather than confidence in their abilities, to use the service, held greater sway in deciding to use the service (Schlaegel, 2015). This may be due to the greater consumer experience with online shopping, and these websites being more user friendly. Contrary to previous findings (Terry and O'Leary, 1995; Conner and Armitage, 1998), perceived control of external barriers (H6) did not influence their online auction usage. Both trust (H9) and security (H11) failed to significantly influence consumer's online auction usage, contradicting previous findings (Pavlou and Gefen, 2005; Shareef et al., 2013, Schlaegel, 2015), which suggested significant roles for trust and security in predicting e-commerce transactions. Importantly for C2C research, although trust significantly influenced transaction intentions, it was not a significant predictor of online transaction behaviours in the current study. Furthermore, perceptions of how secure online auctions are did not influence consumer transaction frequency, which is quite different from what other researchers have reported (Abdelghaffar and Moustafa, 2013). Abdelghaffar and Moustafa (2013) had identified that security issues around consumer information can influence consumer engagement. In contrast, the current research provides no support for this, rather online transactions are based on consumer intentions, and to a lesser extent their confidence in their own ability, to use the service. Finally, these findings demonstrate the importance of the intentionbehaviour relationship, provide clarity on how the consumer is engaged with online auctions, and support the usefulness of the TPB model itself (Ajzen, 1991). 


\section{Implications and future research}

The findings provide further valuable theoretical insight into online auction behaviours, which needed further exploration (Saputra, Warokka and Naruephai, 2012), especially in relation to C2C e-commerce (Leonard, 2012; Lu and Lin, 2012; Schlaegel, 2015). A central implication of this study is that it provides further insight into the role of motivational factors that can influence online auction decisions and transactions (Gopi and Ramayah, 2007; Sanayei and Bahmani, 2012; Hsu et al., 2006). Like Yen and Lu (2008), the current research helps to develop a better understanding of the 'bidder's decision process when taking part in online auction' (p. 41). Furthermore, this study contributes to extending consumer behaviour understanding in an online auction environment (Drake, Hall and Byrd, 2012), adding to the work undertaken by Foxall (1993), Constantinides (2004), and Evans, Jamal and Foxall (2009). More specifically, the current study found attitudes towards using an online auction service, personal abilities (Pavlou and Fygenson, 2006; Huang et al., 2011) and trust (Hou, Ma and Yang, 2011) in the service are important predictors of consumer online transaction intentions.

Furthermore, any marketing messages need to further echo and support the attitudes, in terms of convenience and ease of use, highlighted in this research, as these are crucial in encouraging usage and engagement in an online auction environment. Online auction services, such as eBay, need to continue to communicate messages to enhance consumer confidence, building trust, to enhance consumer's belief in the service provider, and therefore reduce perceived risks (Xu, Lin and Shao, 2010). The attitude and satisfaction related variables, like trust, identified in the current research are therefore invaluable in terms of persuading potential consumers to use the service, and maintaining the existing consumer base in the early stages of buying behaviour. In fact, this message needs to be reinforced at each of the interlinked stages that eBay consumers undertake (Engel, Kollatt and Blackwell, 1993; Gabbott and Hogg, 1998). Future online auction site strategies should take note of these factors when trying to retain existing consumers and when trying to attract new consumers (Chen and Barnes, 2007; Tseng and Teng, 2014). By highlighting factors influencing behavioural intentions, this research can inform online auction sites in ways they could increase their competitiveness. Another strength of this study was that rural, suburban and urban consumer online auction behaviours were accurately represented by an extended TPB model, which can be a valuable tool for a global brand such as eBay.

Commercial and academic research interests would be better served by applying conceptual framework models like the TPB and extending it with the inclusion of other antecedents. Further research could investigate the role of future behaviours (Wahab, Mohd and Ali, 2009) and the impact of past experiences (Lodorfos, Trosterud and Whitworth, 2006; Wu and Teng, 2011) on individual's decisions to use online auctions. Other antecedents such as gender could also be explored regarding online auction behaviours, as previous research has indicated that the motivations for males and females to use online auctions differ (Lai, Wu and Lin, 2008). Evidence such as this could to be further explored within the context of the TPB to examine if two possible models for male and female online transaction intentions and behaviours exist. 


\section{Limitations}

Further geographical locations could have been employed, which would have added more representative scope to the sample. That is, the regions selected for the current study may have shared certain cultural attitudes and perceptions making the sample more homogeneous in nature due to geographical proximity. Thus, a third region could have been employed to explore possible variations and address any cultural variations as suggested by Xu, Lin and Shao (2010). Another sampling related limitation was that individuals attending business events were targeted so the sample itself may not be reflective of those from non-business oriented backgrounds or professions. Lastly, other variables may have explained online auction intentions and behaviours and so we encourage other researchers to examine additional variables like gender. However, as mentioned previously, these antecedents should be integrated within an extended TPB (Ajzen, 1991) framework. Despite these limitations, the authors argue that the current study adds to the existing understanding of online auction site behaviours for academics, online auction practitioners, other $\mathrm{C} 2 \mathrm{C}$ e-retailers, and policymakers.

\section{Conclusion}

In conclusion, some previous research studies have only applied the TPB to exploring online purchasing intentions only (Yen and Lu, 2008a, 2008b), while the current study does much more. The value of the current study lies in predicting the frequency of online auction transactions, through the significant contributions of positive intentions, abilities around online auction transactions and trust. As the research within the $\mathrm{C} 2 \mathrm{C}$ online auctions is relatively new, the current study findings are timely and of great importance as they provide evidence about the role of these drivers. Future research can build on these findings by further extension and application of theoretical frameworks like TPB to understand more about selling and buying in e-commerce sectors.

\section{References}

Abbass, S.M. and Ibrahim, O.B. (2011) 'A model for trust-building in e-commerce from consumer to consumer perspective in KSA', International Journal of e-Education, eBusiness, e-Management and e-Learning, 1(3), pp. 223-222.

Abdelghaffar, H. and Moustafa, H. (2013) 'Exploring the factors affecting the intention to use C2C auction websites in Egypt', International Journal of E-Adoption, 5(2), pp. 1-13.

Ajzen, I. (2015) 'Consumer attitudes and behavior: the theory of planned behavior applied to food consumption decisions', Rivista di Economia Agraria, 70(2), pp. 121-138. [Online]. Available at: 
http://dx.doi.org/10.13128/REA-18003. (Accessed: 5 March 2017).

Ajzen, I. (2011) 'The theory of planned behavior: reactions and reflections', Psychology and Health,9), pp. 1113-1127.

Ajzen, I. (2002)' Perceived behavioral control, self-efficacy, locus of control, and the theory of planned behavior', Journal of Applied Social Psychology, 32(4), pp. 665-683.

Ajzen, I. (1991) 'The theory of planned behavior', Organizational Behavior and Human Decision Processes, 50 (2), pp. 179-211.

Armitage, C. J. and Conner, M. (2001) 'Efficacy of the theory of planned behaviour: a metaanalytic review', British Journal of Social Psychology, 40(4), pp. 471- 499.

Armitage, C. J., and Conner, M. (1999) 'Distinguishing perceptions of control from selfefficacy: predicting consumption of a low-fat diet using the theory of planned behavior', Journal of Applied Social Psychology, 29(1), pp. 72-90.

Armitstead, L. (2013) 'Monday Interview: eBay's Europe boss Clare Gilmartin', The Telegraph, 23 May [Online]. Available at:

http://www.telegraph.co.uk/finance/newsbysector/retailandconsumer/10137939/MondayInterview-eBays-Europe-boss-Clare-Gilmartin.html (Accessed: 10 March 2017).

Bosnjak, M., Obermeier, D. and Tuten, T.L. (2006) 'Predicting and explaining the propensity to bid in online auctions: a comparison of two action-theoretical models', Journal of Consumer Behaviour, 5, pp. 102-116. Business Source Complete, EBSCOhost [Online]. (Accessed: 6 March 2017).

Browne, M. W. and Cudeck, R. (1993) 'Alternative ways of assessing model fit', in Bollen, K. A. and Long, J. S. (eds.) Testing Structural Equation Models. Beverly Hills, CA: Sage, pp. 136-162.

Burke, R. R. (1998) 'Real shopping in a virtual store', in Bradley, S. P. and Nolan, R. L. (eds.) Sense and respond: capturing the value in the network era. Boston, MA: Harvard Business School.

Chellappa, R.K., and Pavlou, P.A. (2002) 'Perceived information security, financial liability and consumer trust in electronic commerce transactions', Logistics Information Management, 15(5/6), pp. 358-368.

Chen, R-S., Chiu, C-C., Chiang, J-C., and Tsai, C-H. (2007)' Research on the purchase behavior of customer-to-customer online auction', Journal of Business and Public Affairs, 1(2), pp.1-8. Available at:

http://citeseerx.ist.psu.edu/viewdoc/summary?doi=10.1.1.129.7579\# (Accessed: 5 March 2017).

Chen, Y-H., and Barnes, S. (2007) 'Initial trust and online buyer behaviour', Industrial Management and Data Systems, 107(1), pp. 21-36. Available at: http://www.emeraldinsight.com/doi/full/10.1108/02635570710719034 (Accessed: 5 February 2017).

Chiu, C-M., Huang, H-Y. and Yen, C-H. (2010) 'Antecedents of trust in online auctions', Electronic Commerce Research and Applications, 9(2), pp. 148-159.

Chiu, C-M., Lin, H.Y., Sun, S.Y. and Hsu, M.H. (2009) 'Understanding customers' loyalty intentions toward online shopping: an integration of technology acceptance model and fairness theory', Behaviour and Information Technology, 28(4), pp. 347-360. 
Chu, H. and Liao, S. (2007) 'Exploring consumer resale behavior in C2C online auctions: taxonomy and influences on consumer decisions', Academy of Marketing Science Review, 11(3), pp. 1-25. ProQuest Central, EBSCO host [Online]. (Accessed: 12 March 2017)

Conner, M. and Armitage, C. J. (1998) 'Extending the theory of planned behavior: a review and avenues for further research', Journal of Applied Social Psychology, 28(15), pp.14291464.

Constantinides, E. (2004) 'Influencing the online consumer's behaviour: the Web experience', Internet Research, 14(2), pp. 111-126. Available at: http://www.emeraldinsight.com/doi/abs/10.1108/10662240410530835 (Accessed: 5 February 2017).

Davidson, R. (2011) 'Web 2.0 as a marketing tool for conference centres', International Journal of Event and Festival Management, 2(2), pp. 117-138.

Delafrooz, N., Paim, L. and Khatibi, A. (2011) 'Understanding consumer's internet purchase intention in Malaysia', African Journal of Business Management, 5 (3), pp. 2837-2846.

Drake, J.R., Hall, D.J. and Byrd, T.A. (2012) 'The importance of individual characteristics on consideration sets for online auction buyers', Journal of Theoretical and Applied Electronic Commerce Research, 7(2), pp.13-30.

Engel, J., Kollatt, D. and Blackwell, P. (1993) Consumer Behaviour. $8^{\text {th }}$ edn. New York, NY: Dryden Press.

Evans, M., Jamal, A. and Foxall, G. (2009) Consumer Behaviour. $2^{\text {nd }}$ edn. West Sussex: Wiley.

Foxall, G. (1993) 'A behaviourist perspective on purchase and consumption', European Journal of Marketing, 27(8), pp. 7-16. ProQuest Central, EBSCOhost [Online]. (Accessed: 15 February 2017).

Gabbott, M. and Hogg, G. (1998) Consumers and Services. Chichester, UK: Wiley.

Gefen, D., Karahanna, E. and Straub, D. W. (2003) 'Trust and TAM in online shopping: an integrated model', MIS Quarterly, 27(1), pp. 51-90. Business Source Complete, EBSCOhost [Online]. (Accessed: 15 February 2017).

Gefen, D. and Straub, D. W. (2004) 'Consumer trust in B2C e-commerce and the importance of social presence: experiments in e-products and e-services', Omega, 32, pp. 407-424.

George, J.F. (2002) 'Influences on the intent to make Internet purchases', Internet Research, 12(2), pp. 165-180.

Gopi, M. and Ramayah, T. (2007) 'Applicability of theory of planned behavior in predicting intention to trade online: some evidence from a developing country', International Journal of Emerging Markets, 2, pp. 348-360. ProQuest Central, EBSCOhost [Online]. Accessed: 15 February 2017.

Gregg, D. G. and Walczak, S. (2008) 'Dressing your online auction business for success: an experiment comparing two e-Bay businesses', MIS Quarterly, 32, 3, pp. 653-670. Business Source Complete, EBSCOhost [Online]. Accessed: 15 February 2017).

Hansen, T. (2008) 'Consumer values, the theory of planned behaviour and online grocery shopping', International Journal of Consumer Studies, 32(2), pp. 128-137. Business Source Complete, EBSCOhost [Online]. (Accessed: 15 February 2017).

Hasbullah, N.A., Osman, A., Abdullah, S., Salahuddin, S.N., Ramlee, N.F. and Soha, H.M. (2016) 'The relationship of attitude, subjective norm and website usability on consumer intention to purchase online: an evidence of Malaysian youth', Procedia Economics and 
Christopher McLaughlin et al.

Finance, 35, pp. 493-502. Available at: http://www.sciencedirect.com/science/article/pii/S2212567116000617 (Accessed: 5 March 2017).

Hou, J. and Elliott, K. (2016) 'Gender differences in online auctions', Electronic Commerce Research and Applications, 17(3), pp.123-133.

Hou, Y., Ma, L., and Yang, D. (2011) 'The strength of trust: discussion on the influencing factors of the Chinese farmers' adoption of mobile agricultural science and technology', International Journal of Innovative Computing, Information and Control, 7(12), pp. 69796989. Available at:

http://www.ijicic.org/ijicic-11-04101h.pdf (Accessed: 15 February 2017).

Hoyle, R. H., and Panter, A. T. (1995) 'Writing about structural equation models', in R. H. Hoyle (ed.) Structural equation modeling: concepts, issues, and applications. Thousand Oaks, CA: Sage Publications, pp. 158-176.

Hsu, M.H., Yen, C.H., Chiu, C-M., and Chang, C.M. (2006) 'A longitudinal investigation of continued online shopping behavior: an extension of the theory of planned behavior', International Journal of Human-Computer Studies, 64(9), pp. 889-904.

Hu, L. and Bentler, P.M. (1999) 'Cutoff criteria for fit indexes in covariance structure analysis: conventional criteria versus new alternatives', Structural Equation Modeling, 6(1), pp. 1-55.

Huang, Y.C., Wu, Y.C., Wang, Y. C., and Boulanger, N.C. (2011) 'Decision making in online auctions', Management Decision, 49(5), pp. 784-800. Emerald Insight, EBSCOhost [Online]. (Accessed: 3 March 2017).

Jack, E. P. and Powers, T. L. (2013) 'Shopping behaviour and satisfaction outcomes', Journal of Marketing Management, 29(13-14), pp.1609-1630.

Kautonen, T., van Gelderen, M., and Tornikoski, E. T. (2013) 'Predicting entrepreneurial behaviour: a test of the theory of planned behaviour', Applied Economics, 45(6), 697-707. Available at: https://papers.ssrn.com/sol3/papers.cfm?abstract id=1943950 (Accessed: 15 February 2017).

King, T., Dennis, C. and Wright, L. (2008) 'Myopia, customer returns and the theory of planned behaviour', Journal of Marketing Management, 24(1-2), pp. 185-203. Business Source Complete, EBSCOhost [Online]. (Accessed: 3 March 2017).

Kline, R.B. (2005) Principles and Practice of Structural Equation Modeling. $2^{\text {nd }}$ edn. New York, NY: The Guilford Press.

Koufaris, M. and Hampton-Sosa, W. (2004) 'The development of initial trust in an online company by new customers', Information \& Management, 41, pp. 377-397.

Lai, M., Wu, W-Y. and Lin, S-M. (2008) 'A qualitative approach for conceptualizing consumer decision-making in online auctions', Advances in Consumer Research, 35, pp. 219-324. Business Source Complete, EBSCOhost [Online]. (Accessed: 3 March 2017).

Lee, M.C. (2009) 'Factors influencing the adoption of internet banking: an integration of TAM and TPB with perceived risk and perceived benefit', Electronic Commerce Research and Applications, 8(3), pp.130-141.

Leonard, L.N.K. (2012) 'Attitude influencers in C2C e-Commerce: buying and selling', Journal of Computer Information Systems, 52(3), pp. 11-17.

Li, R., Chung, T-L. and Fiore, A.M. (2017) 'Factors affecting current users' attitude towards e-auctions in China: An extended TAM study', Journal of Retailing and Consumer Services, 34(1), pp. 19-29. 
Lim, Y.J., Osman, A., Salahuddin, S. N., Romle, A.R., and Abdullah, S. (2016) 'Factors Influencing online shopping behavior: the mediating role of purchase intention', Procedia Economics and Finance, 35, pp. 401-410. Available at: http://www.sciencedirect.com/science/article/pii/S2212567116000502 (Accessed: 10 March 2017).

Lodorfos, G., Trosterud, T. and Whitworth, C. (2006) 'E-consumers' attitude and behaviour in the online commodities market', Innovative Marketing, 2(3), pp. 77-96. Available at: https://businessperspectives.org/media/zoo/applications/publishing/templates/article/assets/i s/pdfjs/web/viewer.php?file=/pdfproxy.php?item id:1755 (Accessed: 15 February 2017).

Lu, H.P. and Lin, K.Y. (2012) 'Factors influencing online auction sellers' intention to pay: an empirical study integrating network externalities with perceived value', Journal of Electronic Commerce Research, 13(3), pp. 238-254. Available at:

http://www.jecr.org/node/46 (Accessed: 15 February 2017).

Lunardo, R. (2011) 'Consumer's perceived control: a critical review and a research agenda', in Dahl, D.W., Johar, G.V. and van Osselaer, S.M.J., (eds.) NA - Advances in Consumer Research Volume 38. Duluth, MN: Association for Consumer Research. Available at: http://www.acrwebsite.org/volumes/v38/acr v38 15953.pdf (Accessed: 2 March 2017).

Miles, J.N.V. and Shevlin, M. (2007) 'A time and a place for incremental fit indices', Personality and Individual Differences, 42(5), pp. 869-874.

Music Trades Corporation (2016) 'Amazon and eBay and their impact on the industry', High Beam Research, 1 November [Online]. Available at: https://www.highbeam.com/doc/1G1-470557831.html (Accessed: 10 March 2017).

Parsons, A. G. (2002) 'Non-functional motives for online shoppers: why we click', Journal of Consumer Marketing, 19(5), pp. 380-392.

Pavlou, P. A. and Fygenson, M. (2006) 'Understanding and predicting electronic commerce adoption: an extension of the theory of planned behavior', Management Information Systems Quarterly, 30(1), pp. 115-143. Business Source Complete, EBSCOhost [Online]. (Accessed: 5 February 2017).

Pavlou, P.A. and Gefen, D. (2005) 'Psychological contract violation in online marketplaces: antecedents, consequences, and moderating role', Information Systems Research, 16(4), pp. 372-399. Business Source Complete, EBSCOhost [Online]. (Accessed: 5 February 2017).

Rauniar, R., Rawski, G.E., Crumbly, J. and Simms, J. (2009) 'C2C online auction website performance: buyer's perspective', Journal of Electronic Commerce Research, 10(2), pp. 56-75. Available at: http://www.csulb.edu/journals/jecr/issues/20092/paper1.pdf. (Accessed: 20 February 2017)

Roggio, A. (2012) 'Getting started with eBay', Practical Ecommerce. Available at: http://www.practicalecommerce.com/Getting-Started-with-eBay (Accessed: 12 March 2017)

Rohm, A. J. and Swaminathan, V. (2004) 'A typology of online shoppers based on shopping motivations', Journal of Business Research, 57(7), pp. 748-757.

Sanayei, A. and Bahmani, E. (2012) 'Integrating TAM and TPB with perceived risk to measure customers' acceptance of internet banking', International Journal of Information Science and Management, 10(1), pp. 25-37

Saputra, R.S., Warokka, A. and Naruephai, N. (2012) 'The key drivers of online consumers' intention to purchase in an online auction: a reference from southeast emerging market', 
Journal of Internet and e-Business Studies, 1(1), pp.1-17. Available at: http://ibimapublishing.com/articles/JIEBS/2012/278071/. (Accessed: 10 March 2017).

Schlaegel, C. (2015) 'Understanding individuals' initial and continued use of online auction marketplaces: a meta-analysis', Management Research Review, 38(8), 855-907.

Shareef, M.A., Archer, A., Fong, W., Rahman, M.O. and Mann, I.J. (2013) 'Online Buying Behaviour and Perceived Trustworthiness', British Journal of Applied Science \& Technology, 3(4), pp. 662-683. Available at:

http://www.journalrepository.org/media/journals/BJAST 5/2013/May/1367641391Shareef342012BJAST2394.pdf. (Accessed: 5 February 2017).

Terry, D. J. and O'Leary, J. E. (1995) 'The theory of planned behaviour: the effects of perceived behavioural control and self-efficacy', British Journal of Social Psychology, 34 (2), pp.199-220.

Tseng, F.C., and Teng, C.I. (2014) 'Antecedents for user intention to adopt another auction site', Internet Research, 24(2), pp. 205-222.

Vijayasarathy, L.R. (2004) 'Predicting consumer intentions to use online shopping: the case for an augmented technology acceptance model', Information \& Management, 41(6), pp. 747-762.

Wahab, S., Mohd, N.A. and Ali, J. (2009) 'Technology trust and e-banking adoption: the mediating effect of customer relationship management performance', The Asian Journal of Technology Management, 2(2), pp. 40-49. Available at:

http://journal.sbm.itb.ac.id/index.php/ajtm/article/view/178/163 (Accessed: 15 February 2017).

Weinberg, B.D. and Davis, L. (2005) 'Exploring the WOW in online-auction feedback', Journal of Business Research, 58(11), pp.1609 - 1621.

Wu, C-S., Cheng, F-F. and Yen, D.C. (2014) 'The influence of seller, auctioneer, and bidder factors on trust in online auctions', Journal of Organizational Computing and Electronic Commerce, 24(1), pp. 36-57.

Wu, K-S. and Teng, Y-M. (2011) 'Applying the extended theory of planned behavior to predict the intention of visiting a green hotel', African Journal of Business Management, 5(17), pp. 7579-7587. Available at:

http://www.academicjournals.org/journal/AJBM/article-full-text-pdf/73F83D316890

(Accessed: 15 February 2017).

Xu, B., Lin, Z. and Shao, B. (2010) 'Factors affecting consumer behaviors in online buy-itnow auctions', Internet Research, 20(5), pp. 509-526.

Yao, M .Z. and Linz, D .G. (2008) 'Predicting self-protections of online privacy', Cyberpsychology and Behaviour, 11(5), pp. 615-617.

Yen, C-H. and Lu, H-P. (2008a) 'Factors influencing online auction repurchase intention', Internet Research, 18(1), pp. 7-25.

Yen, C-H. and Lu, H-P. (2008b) 'Effects of e-service quality on loyalty intention: an empirical study in online auction', Managing Service Quality, 18(2), pp. 127-146.

Yousafzai, S. Y., Pallister, J. G. and Foxall, G. R. (2003) 'A proposal model of e-trust for electronic banking', Technovation, 23, pp. 847-860. 